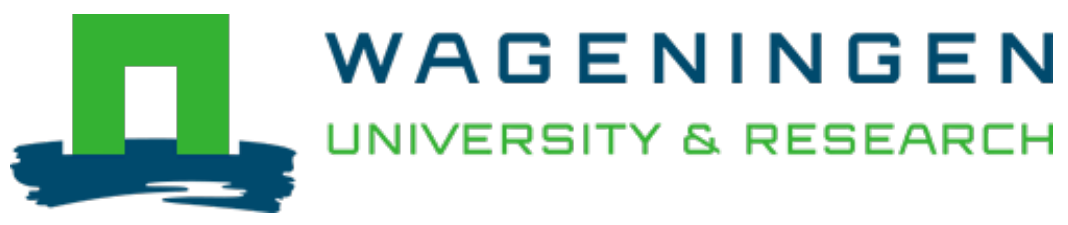

\author{
A computerised system for the identification of lactic acid bacteria. \\ International Journal of Food Microbiology \\ Wijtzes, T.; Bruggeman, M.R.; Nout, M.J.R.; Zwietering, M.H. \\ https://doi.org/10.1016/S0168-1605(97)00084-6
}

This publication is made publicly available in the institutional repository of Wageningen University and Research, under the terms of article $25 \mathrm{fa}$ of the Dutch Copyright Act, also known as the Amendment Taverne. This has been done with explicit consent by the author.

Article $25 \mathrm{fa}$ states that the author of a short scientific work funded either wholly or partially by Dutch public funds is entitled to make that work publicly available for no consideration following a reasonable period of time after the work was first published, provided that clear reference is made to the source of the first publication of the work.

This publication is distributed under The Association of Universities in the Netherlands (VSNU) 'Article $25 \mathrm{fa}$

implementation' project. In this project research outputs of researchers employed by Dutch Universities that comply with the legal requirements of Article $25 \mathrm{fa}$ of the Dutch Copyright Act are distributed online and free of cost or other barriers in institutional repositories. Research outputs are distributed six months after their first online publication in the original published version and with proper attribution to the source of the original publication.

You are permitted to download and use the publication for personal purposes. All rights remain with the author(s) and / or copyright owner(s) of this work. Any use of the publication or parts of it other than authorised under article $25 \mathrm{fa}$ of the Dutch Copyright act is prohibited. Wageningen University \& Research and the author(s) of this publication shall not be held responsible or liable for any damages resulting from your (re)use of this publication.

For questions regarding the public availability of this publication please contact openscience.library@wur.nl 


\title{
Short communication \\ A computerised system for the identification of lactic acid bacteria
}

\author{
T. Wijtzes ${ }^{\mathrm{a}, *}$, M.R. Bruggeman ${ }^{\mathrm{b}}$, M.J.R. Nout ${ }^{\mathrm{b}}$, M.H. Zwietering ${ }^{\mathrm{b}}$ \\ ${ }^{a}$ Unilever Research Laboratory, P.O. Box 114, 3130 AC Vlaardingen, Netherlands \\ ${ }^{\mathrm{b}}$ Wageningen Agricultural University, P.O. Box 8129, 6700 EV Wageningen, Netherlands
}

Received 14 February 1997; received in revised form 2 June 1997; accepted 19 July 1997

\begin{abstract}
A generic computerised system for the identification of bacteria was developed. The system is equipped with a key to the identification of lactic acid bacteria. The identification is carried out in two steps. The first step distinguishes groups of bacteria by following a decision tree with general identification tests. The second step in the identification is the distinction of species within a group on the basis of biochemical fermentation patterns. During grouping, probabilities for test failure are used. These probabilities can be used for assessing the quality of a given test answer. The probabilities are also used to select the most probable test answer in cases where the test result is inconclusive. The probabilities of test failure were determined by a group of experts and a group of potential users of the identification system. During species identification, similarity indices are calculated for all bacteria in a group. The described identification system has the ability to "learn" from different sessions in the species identification step, improving both identification speed and accuracy. Because of the versatile way in which the system is set up, it can very easily be expanded with identification keys to other organisms. () 1997 Elsevier Science B.V.
\end{abstract}

Keywords: Lactic acid bacteria; Computer system; Identification

\section{Introduction}

The group of lactic acid bacteria includes several genera of bacteria that differ considerably in morphological, physiological and functional properties. Consequently, it is essential to have simple and effective methods for the identification of lactic acid bacteria (Cox and Thomsen, 1990). Several commercially available identification kits (e.g. API-50 CHL or API strep) are based on testing the organism's ability to assimilate or ferment a fixed series of

\footnotetext{
*Corresponding author.
}

substrates. The resulting patterns are compared with patterns obtained from tested pure cultures of known origin. The patterns can be analysed manually or with computer programs. The API LAB program is commercially available and discriminates between species on the basis of a pattern-matching principle. Another identification system was described by Cox and Thomsen (1990). Both of these systems assess the entire group of lactic acid bacteria as a whole. In both approaches, the investigator must verify that the organism belongs to the group of lactic acid bacteria. The described programs do not take the basic morphological and physiological variety within the 
heterogeneous group into account. Instead, compensation is sought in the comparison of patterns comprising up to 50 traits. Consequently, numerous traits that are considered will not be of discriminatory value to the genus or species under study. In a group as heterogeneous as the lactic acid bacteria, this approach may lead to wrong species and even wrong genus results.

The computerised identification system for lactic acid bacteria developed in this paper uses a combination of general morphological and physiological characteristics as well as a reasoned selection of carbohydrate fermentation tests. The identification is carried out in two steps. First, the system distinguishes bacteria into groups, using straightforward microbiological tests. Secondly, carbohydrate fermentation patterns are used to discriminate between species.

\section{Materials and methods}

To test the identification system, fourteen stock cultures of lactic acid bacteria were selected and coded. (A) Lactobacillus helveticus (NCIMB 8652), (B) L. delbruekii ss. bulgaricus (DSM 20080), (C) L. halotolerans (ATCC 35410), (D) L. fermentum (UOT 22-0-6), (E) L. plantarum (ATCC det. no number), (F) L. curvatus (LAB 962), (G) Leuconostoc lactis (DSM 20192), (H) Leuconostoc mesenteroïdes ss. mesenteroïdes (DSM 20343), (I) Pediococcus pentosaceus (DSM 20336), (J) Pediococcus dextrinicus (DSM 20335), (K) Streptococcus thermophilus (NCFB 2075), (L) Enterococcus faecalis (DSM 20478), (M) Lactococcus lactis (LMG 2122) and (N) Streptococcus mutans (DSM 20523), where NCIMB is the National Collection of Industrial and Marine Bacteria, Torry Research Station, Aberdeen, UK; DSM is the Deutsche Sammlüng von Mikroorganismen und Zellkulturen, Braunschweig, Germany; ATCC is American Type Culture Collection, Rockville, MD, USA; UOT is the University of Otago, Otago, New Zealand; LAB is Laboratorium voor Microbiologie, Rijksuniversiteit Gent, Gent, Belgium, private collection; LMG is Laboratorium voor Microbiologie, Gent Culture Collection, Rijksuniversiteit Gent, Gent, Belgium and NCFB is the National Collection of Food Bacteria, Shinfield, Reading, UK.
All organisms were stored at $-18^{\circ} \mathrm{C}$ in MRS broth (Oxoid), except for Leuconostoc lactis, which was kept in milk. Prior to the identification procedure, all bacteria were grown aerobically on MRS agar (Oxoid) at $30^{\circ} \mathrm{C}$ for three days. The required tests were carried out according to the appropriate methods as described in standard microbiological handbooks [Gerhardt et al., 1994].

\subsection{Grouping}

The key to grouping is described in Bergey's Manual of Systematic Bacteriology (Holt et al., 1984, 1989). Lactic acid bacteria are distinguished from all other bacteria as being Gram positive, lacking catalase and oxidase, rods or cocci, and the absence of spores and growth under aerobic and anaerobic conditions. After the morphological characteristics are known, the entire group of lactic acid bacteria is split into three groups that are treated separately upon further identification. Lactobacilli are rod-shaped bacteria and Pediococci form tetrads. The group consisting of Streptococcus, Lactococcus, Enterococcus and Leuconostoc form cocci that occur as chains or pairs, which makes it difficult to distinguish these four genera from each other on a morphological basis. All other groups are further differentiated using specific characteristics of each individual group.

\subsection{Conditional chances}

In grouping, all tests have a chance of being misinterpreted. Experts (Faculty members of the Food Microbiology Department of the Wageningen Agricultural University) were asked to predict the chance of misinterpretation of a given test. For instance, given the fact that an organism is a non spore-forming bacterium, estimate the chance that spores can be seen, using the proposed test method. To obtain conditional chances experimentally, fifteen students from undergraduate practical classes were asked to carry out identifications of several preidentified species in different sessions. Their results were compared with the required test results. Then, by applying Bayes' theorem on conditional chances (Lindgren, 1976), the required chances for test 
failure were calculated. In Table 1, the calculated chances are shown for each of the two acquisition methods. Experimentally determined conditional chances are considered to be more reliable and, when available, we therefore used these in the grouping key.

Using conditional chances, test outcomes can be suggested if the result of a performed test is not reliable or is unavailable. Furthermore, certain combinations of test outcomes cannot lead to valid identifications, for instance, catalase-positive lactic acid bacteria. If such a point is reached, the test with the highest probability of failure is checked in the identification key. For this test, the most likely test outcome, that is, with the lowest conditional chance of misinterpretation, is suggested to the user. If the user accepts the proposed outcome, a new identification can be carried out retaining all previously entered information.

\subsection{Species identification}

During the second stage of the identification procedure, carbohydrate fermentation patterns are tested. The carbohydrate fermentation patterns for lactic acid bacteria were derived from Bergey's Manual of Systematic Bacteriology (Holt et al., 1984, 1989). Most group patterns can be matched to reactions available from the API 50 CHL test kit (bioMérieu, 69280 Marcy-l'Etoile, France). The API 20 STREP test kit (bioMérieu) is considered to contain sufficient discriminative tests to discriminate between species in the Streptococcus, Lactococcus and Enterococcus groups.

\subsection{Indices}

For each bacterium in a group of lactic acid bacteria, a similarity index is calculated. In Bergey's

Table 1

Determined chances and conditional chances for the microbial reactions that were used (based on expert opinion and undergraduate determination $^{\mathrm{a}}$ )

\begin{tabular}{|c|c|c|c|c|}
\hline \multirow[t]{2}{*}{ Observed behavior } & \multicolumn{2}{|c|}{$\begin{array}{l}\text { Expert's } \\
\text { chance of being }\end{array}$} & \multicolumn{2}{|c|}{$\begin{array}{l}\text { Undergraduate's } \\
\text { chance of being }\end{array}$} \\
\hline & Correct & Incorrect & Correct & Incorrect \\
\hline Gram positive & 0.85 & 0.15 & & \\
\hline Gram negative & 0.93 & 0.07 & & \\
\hline Aerobic growth & 0.90 & 0.10 & & \\
\hline No aerobic growth & 0.90 & 0.10 & & \\
\hline Anaerobic growth & 0.90 & 0.10 & & \\
\hline No anaerobic growth & 0.90 & 0.10 & & \\
\hline Endospores present & 0.72 & 0.28 & 0.61 & 0.39 \\
\hline Endospores absent & 0.96 & 0.04 & 0.53 & 0.47 \\
\hline Oxidase-positive & 0.90 & 0.10 & 0.94 & 0.06 \\
\hline Oxidase-negative & O.89 & 0.11 & 0.90 & 0.10 \\
\hline Catalase-positive & 0.92 & 0.08 & 1.00 & 0.00 \\
\hline Catalase-negative & 0.96 & 0.04 & 0.64 & 0.36 \\
\hline Gas formation from glucose & 0.96 & 0.04 & & \\
\hline No gas formation from glucose & 0.96 & 0.04 & & \\
\hline Acid formation from ribose & 0.96 & 0.04 & & \\
\hline No acid formation from ribose & 0.96 & 0.04 & & \\
\hline Growth at $15^{\circ} \mathrm{C}$ & 0.98 & 0.02 & & \\
\hline No growth at $15^{\circ} \mathrm{C}$ & 0.96 & 0.04 & & \\
\hline Growth at $45^{\circ} \mathrm{C}$ & 0.98 & 0.02 & & \\
\hline No growth at $45^{\circ} \mathrm{C}$ & 0.94 & 0.06 & & \\
\hline Morphology: Chains of cocci & 0.73 & 0.27 & 0.91 & 0.09 \\
\hline Morphology: Tetrads & 0.80 & 0.20 & 0.92 & 0.08 \\
\hline Morphology: Rods & 0.92 & 0.08 & 0.92 & 0.08 \\
\hline
\end{tabular}

\footnotetext{
${ }^{a}$ Fifteen undergraduate students.
} 
Manual of Systematic Bacteriology (Holt et al., 1984, 1989), it is stated that if at least $90 \%$ of the species of a strain have the ability to ferment a given carbohydrate, it will be tabulated as positive. If $90 \%$ lack the ability to do so, it will be tabulated as negative. For calculation of the similarity index, these values are used. If an entered, experimentally determined test result equals the required, tabulated test result for a reaction, the similarity index for this reaction is set to 0.95 . This value is the mean of 100 and $90 \%$, the value of a corresponding test result. If d-type or 0-type behavior $(\mathrm{d}=11-89 \%$ positive and $0=$ not tested) is recorded in the profile table (Holt et al., 1984, 1989), the similarity index is set to 0.5 . If the experimentally determined test result is different from the required test result, the similarity index of this test is set to 0.05 . For each microorganism, the overall similarity index is calculated as the average similarity indices for all tests.

A match index is also calculated. It is based on positive and negative tabulated test results only; tabulated d-type and 0-type results are not used. This index is calculated as the number of corresponding test results divided by the total number of tests performed. The maximum value of the match index is one. In Table 2, an example of the calculation of both indices is given for Lactobacillus curvatus, as are user-entered results for a few carbohydrate fermentation reactions.

\subsection{Identification procedure}

The most discriminative tabulated test is searched for in the carbohydrate fermentation pattern table.
This test is defined as the tabulated test that separates the entire group of bacteria roughly into two parts, each containing about half of the total number of bacteria. Upon entering the experimental result of the suggested test, the subgroup with the corresponding tabulated test is assessed for further identification. With this subgroup, a new search sequence is carried out, again selecting the tabulated test that divides the subgroup into two equally large, smaller subgroups. Eventually, one organism name remains most likely. As soon as one specific microorganism name is deduced, the results of a user-defined number of other tests are assessed to confirm the identification.

If the described method of species identification fails, that is, the experimentally determined carbohydrate fermentation pattern does not completely match the pattern of one particular organism in the group, similarity or match indices are used to choose the most likely organism from the group. If the match or similarity indices are too low, the grouping stage is entered again, to find the tests that are unreliable.

\subsection{Directed search}

Directed search is based upon the idea that, in a certain environment, specific microorganisms are found more frequently than others. If a certain organism is very often identified, the chance of it being, for instance, a house flora organism is quite large. Therefore, during species identification, attention can be focused on trying to find this particular organism first by carrying out the most discriminative tests for this organism. If the organism cannot be identified by means of the directed search method,

Table 2

Hypothetical example for the calculation of the similarity and match indices for the species identification of Lactobacillus curvatus

\begin{tabular}{lllll}
\hline Reaction & $\begin{array}{l}\text { Required } \\
\text { result for } \\
\text { L. curvatus }\end{array}$ & $\begin{array}{l}\text { User entered } \\
\text { result }\end{array}$ & Similarity index & Match index \\
\hline Amygdalin & Negative & Negative & 0.95 & 1 \\
Glucose & Positive & Negative & 0.05 & 0 \\
Gluconate & Positive & Positive & 0.95 & 1 \\
Lactose & Variable & Negative & 0.50 & Not used \\
Cellobiose & Positive & Positive & 0.95 & 1 \\
Mannitol & Negative & Negative & 0.95 & 1 \\
Mannose & Positive & Positive & 0.95 & 0.83 \\
Calculated index & & & 0.76 & 1 \\
\hline
\end{tabular}


the original species identification method will be used.

\section{Results and discussion}

First, grouping was carried out with the fourteen lactic acid bacteria named above. Table 3 shows the tests proposed by the system and the results obtained for the coded organisms. Species identification following group classification was carried on the basis of data from the API $50 \mathrm{CHL}$ test kit for bacteria A to $\mathrm{J}$, and from the API 20 STREP for bacteria $\mathrm{K}$ to $\mathrm{N}$. The number of confirmatory tests after positive identification of a strain was set to five.

In Table 4, the name of the organism identified for each of the coded organisms is given along with the calculated similarity and match index, in parentheses. The presented indices have not been corrected for the accuracy of the grouping stage. The pilot identification of fourteen bacteria resulted in the accurate identification of most strains. At bacterium code A (see Table 4), three bacteria with equal similarity indices were found. Based on the match index, however, the correct organism was identified. In the case of bacteria codes $\mathrm{K}, \mathrm{M}$ and $\mathrm{N}$, bacteria with two to four similar match indices were deduced. In two instances (bacteria codes $\mathrm{K}$ and $\mathrm{M}$ ), the identification procedure based on the similarity index resulted in an incorrect identification. In both cases, the bac- terium could not be positively identified solely by means of the match index, since more than one bacterium name was deduced. The place where the appropriate organism was found is also shown in the table. These two cases are clear examples of the need for better discriminatory techniques for the species identification of bacteria in the groups of Streptococcus, Enterococcus and Lactococcus. In this respect, an improved method for the identification of Enterococci and fecal Streptococci, as described by Knudson and Hartman (1992), could be introduced into the identification system.

The newly developed computerised system for the identification of lactic acid bacteria uses established methods that are described in renowned identification handbooks for the identification of bacteria. The key to the identification of bacteria is set up in such a way that, with the smallest number of tests, the highest possible certainty is accomplished. The identification key is split up into two parts, one part in which grouping is carried out and the second part in which species are identified.

The novelty of this system can be found in the possibility to reason with both the proposed tests and the test results. If information is not available, gaps can be filled in and answers proposed. Furthermore, information is provided both for the identification route to be followed and the way in which to carry out experiments, with tried and easily practicable tests being suggested.

Table 3

Grouping, tests and results for encoded bacteria

\begin{tabular}{|c|c|c|c|c|c|c|c|c|c|c|c|c|c|c|}
\hline \multirow[t]{2}{*}{ Test $^{\mathrm{a}}$} & \multicolumn{14}{|c|}{ Encoded bacterium } \\
\hline & A & $\mathrm{B}$ & $\mathrm{C}$ & $\mathrm{D}$ & $\mathrm{E}$ & $\mathrm{F}$ & $\mathrm{G}$ & $\mathrm{H}$ & I & $\mathrm{J}$ & $\mathrm{K}$ & $\mathrm{L}$ & M & $\mathrm{N}$ \\
\hline Gram & + & + & + & + & + & + & + & + & + & + & + & + & + & + \\
\hline Aerobic growth & + & + & + & + & + & + & + & + & + & + & + & + & + & + \\
\hline Anaerobic growth & + & + & + & + & + & + & + & + & + & + & + & + & + & + \\
\hline Spore formation & - & - & - & - & - & - & - & - & - & - & - & - & - & - \\
\hline Catalase test & - & - & - & - & - & - & - & - & - & - & - & - & - & - \\
\hline Oxidase test & - & - & - & - & - & - & - & - & - & - & - & - & - & - \\
\hline Morphology $^{\mathrm{b}}$ & 1 & 1 & 1 & 1 & 2 & 2 & 3 & 3 & 2 & 2 & 2 & 2 & 2 & 2 \\
\hline Gas from glucose & - & - & + & + & - & - & + & + & - & - & - & - & - & - \\
\hline Acid from ribose & - & - & nu & nu & + & + & nu & nu & nu & nu & nu & nu & nu & nu \\
\hline Acid from gluconate & - & - & $\mathrm{nu}$ & nu & nu & $\mathrm{nu}$ & nu & nu & nu & nu & nu & nu & nu & nu \\
\hline Growth at $15^{\circ} \mathrm{C}$ & $\mathrm{nu}$ & nu & $\mathrm{nu}$ & nu & nu & nu & + & + & nu & nu & $\mathrm{nu}$ & nu & nu & $\mathrm{nu}$ \\
\hline Growth at $45^{\circ} \mathrm{C}$ & nu & nu & $\mathrm{nu}$ & nu & nu & nu & - & - & nu & nu & + & + & - & - \\
\hline
\end{tabular}

${ }^{\text {a }}$ Symbols used: $+=$ Positive or yes; $-=$ negative or no; nu = not necessary for identification.

${ }^{\mathrm{b}}$ Morphology: 1 = Rods; 2 = chains of cocci; 3 = tetrads. 
Table 4

Coded organism name and identified organisms using a similarity index and a match index

\begin{tabular}{|c|c|c|}
\hline \multirow[t]{2}{*}{ Code and organism name } & \multicolumn{2}{|l|}{ Identified organism } \\
\hline & Similarity index & Match index \\
\hline (A) Lactobacillus helveticus & $\begin{array}{l}\text { Lactobacillus helveticus }(0.86) \\
\text { Lactobacillus delbruekii } \\
\text { ssp.bulgaricus }(0.86) \\
\text { Lactobacillus amylophilus }(0.86)\end{array}$ & Lactobacillus helveticus (1) \\
\hline $\begin{array}{l}\text { (B) Lactobacillus delbruekii } \\
\text { ssp. bulgaricus }\end{array}$ & $\begin{array}{l}\text { Lactobacillus delbruekii } \\
\text { ssp. bulgaricus }(0.95)\end{array}$ & $\begin{array}{l}\text { Lactobacillus delbruekii } \\
\text { ssp. bulgaricus (1) }\end{array}$ \\
\hline (C) Lactobacillus halotolerans & Lactobacillus halotolerans (0.95) & Lactobacillus halotolerans (1) \\
\hline (D) Lactobacillus fermentum & Lactobacillus fermentum (0.85) & Lactobacillus fermentum (1) \\
\hline (E) Lactobacillus plantarum & Lactobacillus plantarum (0.91) & Lactobacillus plantarum (1) \\
\hline (F) Lactobacillus curvatus & Lactobacillus curvatus (0.91) & Lactobacillus curvatus (1) \\
\hline (G) Leuconostoc lactis & Leuconostoc lactis $(0.95)$ & Leuconostoc lactis (1) \\
\hline $\begin{array}{l}\text { (H) Leuconostoc mesenteroides } \\
\text { ssp. mesenteroides }\end{array}$ & $\begin{array}{l}\text { Leuconostoc mesenieroides } \\
\text { ssp. mesenteroides }(0.74)\end{array}$ & $\begin{array}{l}\text { Leuconostoc mesenteroides } \\
\text { ssp. mesenteroides (1) }\end{array}$ \\
\hline (I) Pediococcus pentosaceus & Pediococcus pentosaceus (0.78) & Pediococcus pentosaceus (1) \\
\hline (J) Pediococcus dextrinicus & Pediococcus dextrinicus (0.86) & Pediococcus dextrinicus (1) \\
\hline (K) Streptococcus thermophilus & $\begin{array}{l}\text { Enterococcus salivarius }(0.73) \\
\text { [Streptococcus thermophilus } \\
\quad \text { rated ninth }(0.63)]\end{array}$ & $\begin{array}{l}\text { Streptococcus thermophilus (1) } \\
\text { Streptococcus mitior (1) }\end{array}$ \\
\hline (L) Enterococcus feacalis & Enterococcus feacalis 2 (0.95) & Enterococcus feacalis (1) \\
\hline (M) Lacfococcus lactis & $\begin{array}{l}\text { Streptococcus milneri } 2(0.84) \\
\text { [Lactococcus lactis } \\
\quad \text { rated sixteenth }(0.64)]\end{array}$ & $\begin{array}{l}\text { Lactococcus lactis }(1) \\
\text { Streptococcus sanguis }(1)\end{array}$ \\
\hline & & $\begin{array}{l}\text { Lactococcus lactis } \\
\text { ssp. lactis (1) }\end{array}$ \\
\hline (N) Streptococcus mutans & Streptococcus mutans (0.905) & $\begin{array}{l}\text { Streptococcus mutans }(1) \\
\text { Streptococcus cricetus }(1) \\
\text { Streptococcus sobrinus }(1) \\
\text { Lactococcus piscium }(1)\end{array}$ \\
\hline
\end{tabular}

The described system has the ability to "learn" from different sessions using the principle of directed search. In particular, when the system has run numerous sessions, the number of tests that need to be carried out for species identification can be reduced. This feature is particularly useful when specific house flora have to be identified frequently.

\section{Acknowledgements}

The following strains were kindly provided by the Industrial Microbiology Group, University of Wageningen, Netherlands: Lactobacillus helveticus, Lactobacillus delbrueckii ss. lactis, Lactobacillus halotolerans, Leuconostoc lactis and Streptococcus thermophilis.

\section{References}

Cox, R.P., Thomsen, J.K., 1990. Computer-aided identification of lactic acid bacteria using the API 50 CHL system. Lett. Appl. Microbiol. 10, 257-259.
Gerhardt, P., Murray, R.G.E., Wood, W.A., Krieg, N.R., 1994. Methods for General and Molecular Bacteriology. American Society for Microbiology, Washington, DC.

Holt, J.G., Krieg, N.R., Bergey, D.H., Sneath, P.H.A., Mair, N.S., Sharpe, M.E., Staley, J.T., Wiliams, S.T., 1984. Bergey's Manual of Systematic Bacteriology. Vol. 1, Williams and Wilkins, Baltimore, MD.

Holt, J.G., Krieg, N.R., Bergey, D.H., Sneath, P.H.A., Mair, N.S., Sharpe, M.E., Staley, J.T., Wiliams, S.T., 1989. Bergey's Manual of Systematic Bacteriology. Vol. 4, Williams and Wilkins, Baltimore, MD.

Knudson, L.M., Hartman, P.A., 1992. Routine procedures for isolation and identification of enterococci and fecal streptococci. Appl. Environ. Microbiol. 58, 3027-3031.

Lindgren, B.W., 1976. Statistical Theory. Macmillan, New York. 